\title{
Upaya Penggunaan Metode Telemetri untuk Penelitian Berang-Berang Cakar Kecil (Aonyx cinereus) di Area Persawahan
}

\section{An Effort to Use Telemetry Method on Small-Clawed Otters (Aonyx cinereus) in A Rice Field Landscape}

\author{
Mahfud Huda $\left.{ }^{1 *}\right)$, Jabang Nurdin ${ }^{1)}$, Wilson Novarino'), Hanif Fadly ${ }^{3)}$, Aadrean ${ }^{1,4)}$ \\ 1)Laboratorium Ekologi Hewan, Jurusan Biologi FMIPA Universitas Andalas, Kampus UNAND Limau \\ Manih, Padang-25163 \\ 2)Laboratorium Taksonomi Hewan, Jurusan Biologi, FMIPA Universitas Andalas, Kampus UNAND \\ Limau Manih, Padang-25163 \\ 3)UPTD Balai Laboratorium Kesehatan dan Klinik Hewan, Dinas Peternakan dan Kesehatan Hewan \\ Provinsi Sumatera Barat \\ 4)Graduate School of Natural Science and Technology, Kanazawa University, Japan \\ *Koresponden: mahfudhuda09@yahoo.co.id
}

\begin{abstract}
Currently, telemetry appeared as a common method to reveal home range and movement of animal. However, the telemetry method was not applied for small-clawed otter yet. We have spent efforts to use the telemetry methods from March to August 2016 in a rice field landscape in Lubuk Alung district, Padang Pariaman regency, West Sumatra. We trapped individuals of small-clawed otters (Aonyx cinereus) using leg-hold traps and box traps. We implanted radio transmitter intraperitoneally. Movement of the animal was recorded using triangulation methods. Two male individuals of small-clawed otters were captured. One individual died soon after the transmitter implantation and another individual was successfully implanted and released. However the individual were detected for 28 hours only. In this paper, we described the efforts and problems appeared from the trapping, transmitter implantation, releasing and radio tracking process.
\end{abstract}

Keywords: latrine site, radio transmitter, radio tracking, implant transmitter

\section{Pendahuluan}

Berang-berang cakar kecil (Aonyx cinereus) merupakan salah satu spesies berang-berang dari total 13 spesies yang ada di dunia. Berang-berang cakar kecil lebih kecil dibandingkan dengan spesies berang-berang lain. Kepala dan tubuh berukuran 406-635 $\mathrm{mm}$, panjang ekor 246-304 $\mathrm{mm}$, total panjang dari moncong hingga ujung ekor sekitar 652-939 $\mathrm{mm}$ serta bobot tubuh berkisar antara 2,7-5,4 kg (Walker, 1975). Jejak kaki berang-berang cakar kecil berbeda dengan jejak kaki berang-berang lain dengan ukuran yang lebih kecil (lebar $4,5 \mathrm{~cm}$ ), tidak adanya tanda cakar, selaput jaring yang lengkap antara jari tangan dan kaki, jari tengah lebih panjang dibandingkan dengan jari lainnya dan ukuran jari yang relatif panjang (Lariviere, 2003).

Berang-berang merupakan salah satu hewan yang sangat tergantung pada keberadaan lahan basah (Asmoro et al., 1994). Foster-Turley (1992) menyatakan bahwa area persawahan salah satu habitat penting bagi berang-berang cakar kecil. Saluran air di tepi sawah yang bersemak dan pematang sawah merupakan tempat bersarang spresies ini. Berang-berang cakar kecil menggunakan tumpukan jerami sebagai pengering dan pembersih tubuh serta mencari makan pada daerah berlumpur.

Saluran air di pinggiran sawah biasanya langsung terhubung ke irigasi dan sungai, jalur ini berkemungkinan digunakan 
sebagai jalur pergerakan berang-berang cakar kecil. Salah satu cara yang digunakan untuk mengetahui pergerakan hewan adalah dengan menggunakan radio transmitter. Penggunaan radio transmitter pernah dilakukan pada berang-berang jenis lain yakni Lutra lutra (Arnemo, 1991 dan Fernandez-moran et al., (2002) dan Lontra feline (Soto-Azat et al., 2006). Oleh karena itu dilakukan penelitian dengan menggunakan telemetri untuk mengetahui daerah jelajah dan pergerakan berangberang cakar kecil, sebagai spesies berangberang terkecil di dunia. Artikel ini menjelaskan usaha dan kendala dalam penggunaan telemetri pada penelitian daerah jelajah dan pergerakan berangberang cakar kecil.

\section{Metode Penelitian}

\section{Waktu dan Tempat}

Penelitian ini telah dilaksanakan dari bulan Maret sampai Agustus 2016 di area persawahan kecamatan Lubuk Alung kabupaten Padang Pariaman dan di UPTD balai laboratorium kesehatan dan klinik hewan, Dinas Peternakan Provinsi Sumatera Barat.

\section{Cara Kerja}

Survei pendahuluan dilakukan untuk mencari tanda-tanda keberadaan berangberang cakar kecil dengan berpedoman pada Aadrean (2011) yang sebelumnya telah menemukan jejak keberadaan berangberang cakar kecil pada beberapa lokasi kotoran / Latrine Site (LS) di kecamatan Lubuk Alung untuk kemudian dipasang perangkap. Perangkap yang digunakan adalah berupa perangkap kaki dengan satu pegas dan dua pegas, perangkap kotak kawat dan multiplek. Hewan yang tertangkap dipasang sebuah transmitter ke dalam intraperitonial mengikuti petunjuk Ó Néill et al. (2008), yang dilakukan oleh dokter hewan. Pelacakan sinyal radio dilakukan pada pukul 11.00-14.00 WIB, 20.00-21.00 WIB, 00.00- 01.00 WIB dan 05.00-07.00 WIB. Penentuan lokasi berangberang ditentukan berdasarkan triangulation method (Quagliettaet et al., 2014). Penentuan lokasi hewan target berdasarkan pemusatan dari sinyal yang diterima yang diambil dari dua titik atau lebih.

\section{Analisis Data}

Data kondisi fisik disajikan berupa deskripsi kondisi fisik berang-berang cakar kecil pada saat penangkapan serta saat pelepasan. Data pergerakan posisi berangberang cakar kecil berdasarkan pelacakan sinyal radio menggunakan metode triangulasi dianalisis dengan menggunakan perangkat lunak QGIS dan Google Earth yang kemudian ditampilkan dalam bentuk peta.

\section{Hasil dan Pembahasan}

\section{Penangkapan Berang-berang Cakar Kecil}

Penangkapan berang-berang cakar kecil telah dilakukan dengan menggunakan tujuh unit perangkap kaki selama 39 hari, perangkap kotak dari kawat sebanyak satu unit selama dua belas hari dan perangkap kotak multiplek sebanyak lima unit selama 28 hari. Dari usaha tersebut hanya tertangkap dua individu jantan dewasa hidup, terdiri dari satu individu menggunakan perangkap kaki dua pegas dan satu individu lainnya menggunakan perangkap kotak multiplek.

Kurangnya jumlah perangkap kaki menjadi salah satu faktor penangkapan yang kurang efektif. Penelitian ini menggunakan perangkap kaki produksi Sakae Industry Jepang seri YK22 (satu pegas) sebanyak enam unit dan YK23 (dua pegas) sebanyak satu unit. Pemasangan perangkap kaki dengan satu pegas dinilai kurang efektif. Hal itu dibuktikan dengan terlepasnya berang-berang yang tertangkap sebanyak lima kali. Tidak efektifnya perangkap kaki satu pegas dikarenakan kurangnya kekuatan perangkap satu pegas dibandingkan dengan perangkap dua pegas.

Serfass et al. (1996) menyatakan tipe perangkap kaki pegas sebanyak 60-315 buah bisa memperoleh satu individu/perangkap malam. Belfiore (2008) 
melakukan penangkapan berang-berang sungai (Lontra canadensis) menggunakan perangkap kaki dua pegas dan berhasil menangkap satu individu setiap 48 perangkap malam. Fernandez-Moran et al. (2002) melakukan total usaha penangkapan menggunakan perangkap kaki sebanyak 8.773 perangkap malam dengan 55 individu berang-berang yang terperangkap (159 perangkap malam per individu).

Satu individu (M1) tertangkap perangkap kaki dua pegas pada rentang waktu pukul 20.30 WIB sampai 05.30 WIB. Berang-berang yang tertangkap dimasukkan ke dalam tangguk jaring lalu perangkap jepit kaki dilepaskan dan dimasukkan dalam kandang hewan. Berang-berang yang masih dalam jaring selanjutnya langsung dibawa ke Balai Klinik Hewan. Namun individu ini akhirnya mati dalam proses pemasangan transmitter (detailnya dijelaskan di sub-bab Pemasangan Implant Transmitter). Teknik penanganan yang seperti ini diduga menyebabkan berangberang semakin stres dan dapat menyebabkan kematian.

Proses penangkapan hewan liar yang menggunakan perangkap kaki dapat menimbulkan luka fisik ataupun stres karena perangkap terbuat dari baja walaupun dilapisi karet pelindung, maka lebih baik menggunakan perangkap kandang agar hewan yang tertangkap merasa nyaman (Iossa et al., 2007).

Usaha lain yang dapat digunakan untuk meminimalisir stres saat penangkapan berang-berang menggunakan perangkap kaki yaitu dengan menggunakan alat tambahan yakni sistem alarm yang akan memberikan pesan ke telepon genggam peneliti bahwa perangkap telah tertutup (Ó Néill et al., 2007). Cara lain menggunakan perangkap transmitter yang memancarkan sinyal saat perangkap tertutup, memungkinkan untuk menangani hewan yang tertangkap lebih cepat. Hal ini dapat mengurangi atau menghindari kematian karena kehabisan tenaga dan predasi (American Veterinary Medical Association, 2008).

Penangkapan selanjutnya menggunakan perangkap kotak yang terbuat dari rangka besi kawat dan rangka multiplek.
Perangkap kotak multiplek berhasil mendapatkan satu individu berang-berang dan pada perangkap kotak kawat juga tertangkap satu individu berang-berang namun lepas dengan cara merusak pintu kawat belakang.

Melissen (2000) menyatakan untuk menangkap hewan liar seperti berangberang penggunaan perangkap kotak lebih efesien dan aman. Perangkap harus lebih panjang dari pada ukuran tubuh berangberang serta memiliki dua sisi pintu yang bisa terbuka dan tertutup dan sisi atas yang juga bisa terbuka.

Awalnya penangkapan berangberang menggunakan perangkap kotak dilakukan dengan menggunakan umpan berupa kotoran yang diambil dari lokasi pemasangan perangkap tersebut. Namun perlakuan ini tidak berhasil. Hal itu dibuktikan dengan adanya kadatangan berang-berang cakar kecil pada malam harinya dengan adanya kotoran baru dan hasil foto perangkap kamera, namun tidak masuk kedalam perangkap dan hanya melewati perangkap saja.

Pemasangan perangkap berikutnya dilakukan dengan menggunakan kotoran yang berasal dari lokasi berjarak $7 \mathrm{~km}$. Hasilnya seekor berang-berang cakar kecil masuk ke dalam perangkap kotak kawat dan ditemukan kotoran baru. Masuknya berangberang cakar kecil dalam perangkap diasumsikan bahwa umpan kotoran dari lokasi kotoran yang lain berasal dari kelompok yang berbeda, sehingga membuat keadaan terancam di daerah teritorinya dan masuk ke dalam perangkap. Pada penangkapan dengan perangkap kotak kawat ini, berang-berang cakar kecil berhasil keluar merusak pintu belakang. Perangkap kotak kawat yang rusak diganti dengan perangkap kotak kayu multiplek dengan menggunakan kotoran dari lokasi lain. Saat pengecekan perangkap kotak multiplek ditemukan satu individu jantan. Masuknya individu dalam perangkap kotak yang diisi kotoran dari lokasi lain diduga karena adanya respon dari perasaan terancam oleh kedatangan kelompok lain di daerahnya. Namun, asumsi ini tidak kuat karena pada perangkap kotak di lokasi lainnya tidak didapatkan berang-berang 
cakar kecil walaupun lokasi tersebut didatangi oleh berang-berang dengan adanya tanda-tanda kedatangan berangberang cakar kecil berupa hasil foto pada perangkap kamera, jejak kotoran, jejak kaki dan jejak rumpun padi. Oleh karena itu penggunaan kotoran untuk dijadikan umpan dinilai masih belum efektif.

\section{Pemasangan Implant Transmitter}

Berang-berang cakar kecil yang berhasil ditangkap untuk dipasang implant transmitter sebanyak dua individu jantan dewasa yakni M1 yang ditangkap menggunakan perangkap jepit kaki dan M2 yang ditangkap menggunakan perangkap kotak multiplek. Proses pemasangan implant transmitter pada kedua individu ini terdapat perbedaan yakni pada jenis perangkap, ukuran tubuh, pencukuran rambut pada M1, waktu dan durasi setiap pembedahan. Data pengukuran karakter morfologi berang-berang cakar kecil ditampilkan pada Tabel 1 dan waktu dan durasi setiap tahapan pemasangan transmitter terdapat pada Tabel 2.

Tabel 1. Pengukuran Karakter Morfologi Berang-Berang Cakar Kecil (Aonyx cinereus)

\begin{tabular}{|c|c|c|c|c|c|c|c|c|}
\hline \multirow{2}{*}{$\begin{array}{c}\text { Indivi } \\
\text { duf }\end{array}$} & \multirow[t]{2}{*}{ JK } & \multirow{2}{*}{$\begin{array}{l}\text { BB } \\
(\mathrm{kg})\end{array}$} & \multirow{2}{*}{$\begin{array}{l}\text { PT } \\
(\mathrm{cm})\end{array}$} & \multirow{2}{*}{$\begin{array}{l}\mathrm{PE} \\
(\mathrm{cm})\end{array}$} & \multirow{2}{*}{$\begin{array}{l}\text { TB } \\
(\mathrm{cm})\end{array}$} & \multirow{2}{*}{$\begin{array}{l}\mathrm{LB} \\
(\mathrm{cm})\end{array}$} & \multicolumn{2}{|c|}{ Rumus Gigi } \\
\hline & & & & & & & Atas & Bawah \\
\hline M1 & Jantan & 3,01 & 73 & 28,5 & 11 & 7 & 3122 & 3123 \\
\hline M2 & Jantan & 2,6 & 68 & 24 & 9,5 & 6 & 3122 & 3123 \\
\hline
\end{tabular}

Keterangan : JK (jenis kelamin), BB (berat badan), PT (panjang total), PE (panjang ekor), TB (tinggi badan, diukur dari punggung ke bawah perut), LB (lebar badan, diukur pada perut)

Berdasarkan data pengukuran tubuh individu M1 dan M2 diperkirakan sudah bisa dilakukan pemasangan transmitter karena hewan sudah dalam kategori dewasa. Transmitter yang digunakan adalah LPI-3180 produksi dari Wildlife Materials International Inc dengan ukuran panjang 6 $\mathrm{cm} \times$ lebar $1,5 \mathrm{~cm} \times$ tinggi $2 \mathrm{~cm}$ serta memiliki berat 30 gr. Sebelumnya, Ó Néill et al. (2008) telah menggunakan transmitter bentuk tabung dengan ukuran $8,5 \mathrm{~cm} \times 2$ $\mathrm{cm}$ beratnya 28 gr atau $0,7 \%$ dari rata-rata berang-berang yang ditangkap.
Berdasarkan Tabel 1 ukuran tubuh individu M1 lebih besar daripada individu M2, namun hal tersebut tidak berhubungan dengan kesuksesan pemasangan pada individu M1. Individu M1 tidak sampai pada proses pelepasan karena hewan mati saat tahap akhir penjahitan. Pada sampel M2 transmitter berhasil dipasangkan. Kesuksesan pemasangan implant transmitter pada M2 diduga karena hewan tidak terlalu stres saat penangkapan dan pembawaan ke klinik hewan.

Tabel 2. Waktu atau durasi pada setiap tahapan pemasangan implant transmitter

\begin{tabular}{llll}
\hline & \multicolumn{1}{c}{ M1 } & \multicolumn{1}{c}{ M2 } \\
\hline Waktu/durasi & Tahapan & Waktu/Durasi & Tahapan \\
\hline 09.28 & Premedikasi (atropine & 13.22 & Premedikasi (atropine sulfat) \\
& sulfat) & & \\
09.37 & Anasthesi umum & 13.24 & Anasthesi umum \\
10.03 & Mulai pembedahan & 13.31 & Mulai pembedahan \\
10.43 & Transmitter dipasang & 13.42 & Transmitter dipasang \\
10.50 & Denyut jantung berhenti / & 14.02 & Operasi selesai \\
& koma & & \\
10.55 & Suntik epinephrine saat & $14.02-17.15$ & Istirahat di kandang \\
\multirow{2}{*}{11.00} & koma & $16.45-18.20$ & $\begin{array}{l}\text { Dibawa dari klinik hewan ke lokasi } \\
\text { pelepasan }\end{array}$ \\
& Dipastikan mati & 19.38 & Pelepasan \\
\hline
\end{tabular}


Berdasarkan Tabel 2 terdapat perbedaan rentang waktu penangkapan dengan mulainya pembedahan antara M1 dan M2. Waktu istirahat setelah penangkapan pada M2 lebih banyak daripada M1 yakni selisih waktu 4 jam. Hal ini juga diduga salah satu penyebab ketidakberhasilan dalam implant transmitter pada M1. Pada M1 hewan mengalami stres yang tinggi ditandai dengan adanya indikasi pembengkakan pada jantung setelah dilakukan pembedahan.

Peningkatan stres juga terjadi karena pada saat proses penangkapan, perangkap jepit kaki melukai kaki depan sebelah kiri, melukai dagu dan mematahkan satu gigi premolar. Selain itu proses pembawaan ke klinik hewan dengan kondisi hewan dalam tangguk dalam kandang hewan dan kandang yang tidak ditutup sehingga cahaya matahari masuk ke dalam kandang juga diduga menambah tingkat stres pada hewan ini. Sedangkan M2 berada dalam perangkap kotak kayu multiplek mulai dari masuk terperangkap, tranportasi ke klinik hewan dan di siram dengan air supaya kondisi dalam perangkap tetap terjaga lembab dan sejuk sehingga dapat mengurangi tingkat stres.

Perbedaan proses pemasangan implant transmitter yang sangat mendasar adalah mengenai kondisi fisik dan perilaku berang-berang cakar kecil setelah penangkapan. M1 yang ditangkap menggunakan perangkap jepit kaki mengalami stress yang tinggi serta dilakukan proses pembedahan pada hari yang sama merupakan faktor ketidakberhasilan implant transmitter.

Hasil yang lebih efisien diperoleh pada M2 yang ditangkap dengan menggunakan perangkap kotak. M2 tidak banyak mengalami luka serta memperlihatkan perilaku yang tenang dan tidak terlalu stres sehingga sukses dalam proses implant transmitter. Pada penelitian sebelumnya, Ó Néill et al. (2008) berhasil melakukan pemasangan transmitter sekitar 3 jam setelah penangkapan dan pelepasan setelah pembedahan. Berang-berang dilepaskan masih dalam teritorinya dan tidak mengalami gangguan saat membuang kotoran.

Pada proses pemasangan, kedua individu dimasukkan ke dalam tangguk jaring, lalu diletakkan diatas meja. Setelah itu diberikan suntik penenang atau premedikasi pada daerah subkutan menggunakan atropine sulfat $0,3 \mathrm{mg}(0,1$ $\mathrm{mg} / \mathrm{Kg}$ berat tubuh), lalu di beri suntik bius zoletil $10 \mathrm{mg}(3,33 \mathrm{mg} / \mathrm{Kg}$ berat tubuh). Setelah tidak sadarkan diri, dibawa ke ruangan operasi, diletakkan di meja bedah, lalu diberikan bius total melalui inhalasi, menggunakan isoflurane yang konsentrasinya diatur antara 1-2 ppm, diberikan sesuai kondisi kesadarannya. Metoda bius yang digunakan lebih bagus dibandingkan penelitian sebelumnya yang tidak menggunakan bius melalui inhalasi. Soto-Azat et al. (2011) menggunakan suntikan kombinasi ketamine $5 \mathrm{mg} / \mathrm{kg}$ dan medetomidine $50 \mu / \mathrm{kg}$. Fernandez-Moran et al, (2002), memberikan suntikan bius dilapangan kombinasi ketamine $5 \mathrm{mg} / \mathrm{kg}$ dan medetomidine $50 \mu \mathrm{g} / \mathrm{kg}$ saat tertangkap di lapangan dalam kotak kayu.

Berang-berang diletakkan dalam posisi rebah lateral, incisi pembedahan dilakukan pada daerah flank kanan. Penelitian sebelumnya, Arnemo (1991) melakukan pembedahan di bagian perut, punggung hewan dibaringkan dan di bedah $7-8 \mathrm{~cm}$ sampai mendekati pusat. Ó Néill et al. (2008) melakukan implant transmitter di bagian punggung sebelah kanan dan berhasil.

Sebelum dilakukan pembedahan terhadap indidvidu M1, rambut disekitar bagian tubuh antara tulang rusuk dengan tulang panggul atau biasa disebut daerah flank dicukur sekitar $6 \times 6 \mathrm{~cm}$, namun individu M2 tidak dilakukan pencukuran rambut. Pembedahan dilakukan secara transversal plane sampai lapisan intraperitoneal. Transmitter yang sudah steril ditanam secara transversal plane pada bagian cavum abdomen tersebut. Lapisan epidermis dan endodermis yang tersayat pada proses pembedahan dijahit dan diberikan krim penicillin di sekitar sayatan pembedahan sekitar 2-3 cm. Rambut pada area pembedahan yang dicukur tidak jauh berbeda dengan yang dilakukan Arnemo 
(1991) dengan area pembedahan 7-8 cm. Fernandez-Moran et al. (2002) telah melakukan pencukuran rambut di sekitar area pembedahan seluas 5-6 x $4 \mathrm{~cm}^{2}$ secara ventral dari tubuh, serta pemberian kombinasi penicillin dengan streptomycin 0,5 $\mathrm{ml}$ setelah pembedahan berang-berang.

Pada saat penjahitan lapisan kulit epidermis, individu M1 mengalami koma yang ditandai dengan penurunan drastis detak jantung. Oleh sebab itu diberikan suntikan epinephrine untuk merangsang kembali kerja jantung. Setelah lima menit tidak terjadi peningkatan kerja jantung, akhirnya jantung berhenti berdetak hingga dokter menyatakan berang-berang tersebut sudah mati.

Pada individu M2, setelah dilakukan pemasangan implant transmitters kemudian diawasi di dalam kandang hingga kondisi kesehatan tubuhnya membaik. Setelah itu dokter hewan memeriksa kondisi kesehatan tubuh berang-berang dan membuat keputusan berang-berang tersebut bisa dilepaskan. Berang-berang kemudian dilepaskan kembali di lokasi yang sama pada saat tertangkap tanpa diberi makanan dengan waktu yang dibutuhkan untuk membawa kembali ke lokasi penangkapan sekitar 3 jam .

Fernandez-Moran et al. (2002) melakukan implant transmitter pada berang-berang, setelah selesai dilakukan pemasangan implant transmitter, maka ditempatkan kembali dalam perangkap kotak. Lalu 15 menit setelahnya disuntikkan $250 \mu \mathrm{g} / \mathrm{kg}$ atipamezole dan diberikan makanan 3-5 jam didalam kandang. Waktunya membawa berang-berang lokasi pelepasan selama 2 jam. Kematian hewan biasanya terjadi seminggu hingga sebulan setelah pelepasan.

\section{Hasil Pemeriksaan Post-Mortem Individu MI}

Pemeriksaan post-mortem dilakukan terhadap individu M1 yang mengalami kematian untuk mengetahui kondisi cedera untuk mengetahui faktor ketidakberhasilan pemasangan transmitter. Setelah dilakukan pemeriksaan, ditemukan cedera pada bagian kaki depan sebelah kiri, bagian dagu, gigi premolar patah dan organ jantung membengkak. Kondisi transmitter berada di dalam bagian intraperitonial dengan posisi transverse plane.

Kaki depan sebelah kiri yang terjepit perangkap mengalami luka robek berdarah yang melebar, namun tulang kaki tidak patah. Luka robek dapat terjadi dikarenakan terlalu lamanya kaki terperangkap hingga perangkap dilepaskan, sehingga semakin seringnya hewan tersebut berusaha melepaskan kaki dari perangkap. Gigi premolar bagian bawah patah dan berdarah kemungkinan disebabkan hewan berusaha melepaskan kaki yang terperangkap dengan cara menggigit perangkap jepit kaki yang terbuat dari logam.

Cedera pada gigi juga terjadi pada penelitian Blundell et al., (1999) yang juga mengalami keretakan gigi premolar atau geraham depan pada berang-berang sungai (Lontra canadensis) akibat adanya usaha menggigit perangkap hancock dan perangkap jepit kaki. Belfiore (2008) menyatakan berang-berang yang tertangkap mengakibatkan gigi taringnya sumbing dan pergelangan kakinya terluka.

Bagian dagu yang terluka dan berdarah diduga terjadi bersamaan dengan patahnya gigi, yakni saat menggigit perangkap jepit kaki sehingga dagu tergores ke bagian yang agak tajam dari perangkap tersebut. Kondisi cedera dibagian luar seperti ini diduga menjadi salah satu penyebab berang-berang cakar kecil mati saat implant transmitter.

\section{Kondisi Fisik dan Perilaku Individu M2}

Individu M2 mengalami luka lecet pada hidung yang diduga karena gesekan hidung ke dinding perangkap kotak kayu multiplek sebagai upaya untuk menggigit dinding perangkap. Kondisi kuku, gigi dan bagian tubuh lain tidak mengalami cedera. Perilaku individu M2 di dalam perangkap kotak multiplek terlihat tidak begitu merasa terancam dengan tidak adanya banyak pergerakan terjadi di dalam perangkap selama perjalanan ke klinik hewan. Hal ini disebabkan kondisi di dalam perangkap gelap dan lembab karena disirami dengan 
air. Pada saat dikeluarkan dari perangkap dan diletakkan di atas meja di klinik hewan, perilaku M2 cenderung agresif. Hal itu diduga disebabkan hewan itu melihat banyak orang, adanya cahaya lampu dan dimasukkan dalam tangguk jaring yang menghambat pergerakannya.

Setelah selesai pemasangan implant transmitter, Individu M2 diletakkan kembali ke dalam perangkap kotak multiplek dengan kondisi setengah sadar. Hingga akhirnya setelah tiga jam hewan ini baru sadar dengan kondisi tenang, kemudian dibawa menggunakan kendaraan roda dua ke lokasi penangkapan dengan jarak tempuh 2 jam 30 menit. Setelah itu dilakukan proses pelepasan di lokasi penangkapan. Pada saat pintu kandang dibuka, individu M2 keluar dari perangkap bergerak dengan cepat dan langsung menuju aliran air tepi sawah. Oleh sebab itu, kondisi fisik hewan ini saat pelepasan diduga kuat, sehat dan tidak mengalami cedera dan berperilaku normal.

\section{Pelacakan Sinyal Radio (Radio Tracking)}

Pemantauan pergerakan individu M2 dilakukan selama berturut-turut 7 hari setelah pelepasan kembali ke lokasi penangkapan. Pelacakan sinyal radio dilakukan pada empat waktu pengamatan setiap harinya yang diasumsikan sudah mewakili kemungkinan aktifitas pergerakan spesies tersebut yaitu pagi subuh, siang, senja, dan tengah malam.

Pelacakan sinyal radio dilakukan di beberapa lokasi kotoran berang-berang cakar kecil yang dekat dengan lokasi pelepasan. Terdapat sembilan lokasi kotoran pelacakan sinyal radio (Lampiran 1). Selain karena dekat dengan lokasi pelepasan, pelacakan pada lokasi tersebut juga didukung oleh keberadaan aliran air tepi sawah didekat lokasi pelepasan yang masih satu aliran. Sehingga kemungkinan lintas pergerakan berang-berang berada di sepanjang aliran air tersebut. Pada sekitar lokasi pelepasan terdapat pohon kelapa, rumpun bambu yang berhubungan dengan aliran air, semak belukar, kolam ikan yang berisi ikan, bekas kolam ikan, terowongan aliran air, rumah warga dan irigasi yang mengalir ke aliran air tepi sawah.

Setelah pelacakan sinyal radio dilakukan di sepanjang Sembilan lokasi yang diperkirakan memiliki hubungan dengan aliran air tepi sawah sebagai lintasan berang-berang dengan lokasi pelepasan maka keberadaan sinyal radio hanya ditemukan di lokasi kotoran LS12 dan lokasi pelepasan (LS17) . LS12 merupakan lokasi kotoran yang paling dekat dengan lokasi pelepasan (Lampiran 2).

dari $\begin{gathered}\text { Setelah titik-titik keberadaan sinyal } \\ \text { berang-berang ditemukan }\end{gathered}$ menggunakan radio, maka ditentukan titik dimana posisi berang-berang menggunakan metode triangulasi (Lampiran 3). Hasil pelacakan sinyal radio diperoleh sebaran titik lokasi keberadaan individu M2 seperti pada Tabel 3. Setelah dilepaskan pada pukul 19:38 WIB, maka langsung dipantau arah pergerakan pertamanya. Terdeteksi sinyal kuat karena bergerak ke dalam semak yang tidak jauh dari lokasi pelepasan. Individu M2 hanya bisa terdeteksi selama 3 hari. Sinyal yang tidak terdeteksi disebabkan oleh beberapa kemungkinan seperti hewan M2 masuk kedalam lubang di sekitar lokasi dan bergerak cepat menyusuri saluran air sawah sehingga tidak terpantau oleh receiver radio. Jika individu M2 masuk ke dalam lubang atau bergerak cepat dari jarak deteksi radio, kemungkinan tidak akan terlalu jauh dari lokasi pelepasan. Hal ini dikarenakan setelah 18 jam sejak pelepasan pertama, yakni pada pukul 00.00 WIB, sinyal ditemukan lagi diperkirakan sekitar $200 \mathrm{~m}$ ke arah bawah aliran air tepi sawah dari lokasi pelepasan. Setelah dilakukan pencarian lebih dekat, sinyal tidak lagi dapat dipantau.

Ada kelemahan dalam penggunaan transmitter tipe implant jika dibandingkan dengan transmitter yang dipasang di luar tubuh, yaitu jangkauan sinyal akan berkurang hingga $50 \%$ dari jangkauan normal. Selain itu juga akan meningkatkan gangguan terhadap tubuh hewan yang dapat mengakibatkan bias data yang lebih besar dan memerlukan bantuan penanganan dokter hewan (Haney, 2007). 
Tabel 3. Hasil pemantauan berang-berang cakar kecil melalui Radio Tracking

\begin{tabular}{|c|c|c|c|c|c|c|}
\hline Tanggal & $\begin{array}{l}\text { Pukul } \\
\text { (WIB) }\end{array}$ & $\begin{array}{l}\text { Koordinat sinyal } \\
\text { pemantauan }\end{array}$ & $\begin{array}{l}\text { Kualita } \\
\text { s sinyal }\end{array}$ & $\begin{array}{c}\text { Arah } \\
\text { sinya } \\
1\end{array}$ & $\begin{array}{l}\text { Titik koordinat } \\
\text { pemusatan }\end{array}$ & $\begin{array}{l}\text { Rata-rata suhu } \\
\text { dan } \\
\text { kelembapan }\end{array}$ \\
\hline $15 / 08 / 2016$ & $19: 38$ & \multicolumn{5}{|c|}{$\begin{array}{c}\text { Koordinat Pelepasan } \\
\text { S } 0.64187^{\circ}, \text { E } 100.32053^{\circ}\end{array}$} \\
\hline \multirow[t]{6}{*}{$15 / 08 / 2016$} & $19: 40$ & S $0.64187^{\circ}$ & Kuat & $350^{\circ}$ & \multirow{3}{*}{$\begin{array}{l}\text { S } 0.64152^{\circ} \\
\text { E100.32054 }\end{array}$} & \multirow{3}{*}{$\begin{array}{c}00: 00-01: 00 \\
26,6^{\circ} \mathrm{C} \text { dan } \\
88,4 \%\end{array}$} \\
\hline & $19: 45$ & $\begin{array}{l}\text { E } 100.32048^{\circ} \\
\text { S } 0.64170^{\circ} \text {, } \\
\text { E } 100.32041^{\circ}\end{array}$ & Kuat & $24^{\circ}$ & & \\
\hline & $19: 48$ & $\begin{array}{l}\text { S } 0.64165^{\circ} \\
\text { E } 100.32050^{\circ}\end{array}$ & Kuat & $309^{\circ}$ & & \\
\hline & $23: 27$ & $\begin{array}{l}\text { S } 00.64130^{\circ} \\
\text { E } 100.32117^{\circ}\end{array}$ & Kuat & $245^{\circ}$ & \multirow[t]{3}{*}{$\begin{array}{l}\text { S 0.64164 } \\
\text { E } 100.32044^{\circ}\end{array}$} & \multirow{3}{*}{$\begin{array}{c}06: 00-07: 00 \\
25,12^{\circ} \mathrm{C} \text { dan } \\
87,6 \%\end{array}$} \\
\hline & $23: 32$ & $\begin{array}{l}\text { S } 00.64172^{\circ} \\
\text { E } 100.32007^{\circ}\end{array}$ & Kuat & $80^{\circ}$ & & \\
\hline & $23: 37$ & $\begin{array}{l}\text { S } 00.64194^{\circ} \\
\text { E } 100.32040^{\circ}\end{array}$ & Kuat & $345^{\circ}$ & & \\
\hline \multirow[t]{3}{*}{$16 / 08 / 2016$} & 06:09 & $\begin{array}{l}\text { S 0.64130', } \\
\text { E } 100.32117^{\circ}\end{array}$ & Sedang & $245^{\circ}$ & \multirow[t]{2}{*}{$\begin{array}{c}\text { S } 0.64162^{\circ} \\
\text { E } 100.32042^{\circ}\end{array}$} & \multirow[t]{2}{*}{$\begin{array}{c}34,06^{\circ} \mathrm{C} \text { dan } \\
70,6 \%\end{array}$} \\
\hline & $06: 25$ & $\begin{array}{l}\text { S } 0.64172^{\circ}, \\
\text { E } 100.32007^{\circ}\end{array}$ & Sedang & $80^{\circ}$ & & \\
\hline & $06: 30$ & - & & & \multirow{4}{*}{$\begin{array}{l}\text { S } 0.64266^{\circ} \\
\text { E } 100.31943^{\circ}\end{array}$} & \multirow{4}{*}{$\begin{array}{c}21: 00-22: 00 \\
27,64^{\circ} \mathrm{C} \text { dan } \\
83,8 \%\end{array}$} \\
\hline \multirow[t]{3}{*}{$17 / 08 / 2016$} & 00:00 & $\begin{array}{l}\text { S } 0.64239^{\circ} \\
\text { E } 100.31948^{\circ}\end{array}$ & Lemah & $180^{\circ}$ & & \\
\hline & $00: 30$ & $\begin{array}{l}\text { S } 0.64248^{\circ} \\
\text { E } 100.31937^{\circ}\end{array}$ & Lemah & $170^{\circ}$ & & \\
\hline & $00: 44$ & $\begin{array}{l}\text { S } 0.64253^{\circ} \\
\text { E } 100.31921^{\circ}\end{array}$ & Lemah & $90^{\circ}$ & & \\
\hline
\end{tabular}

$\begin{array}{rrcr}\text { Pemasangan } & \text { alat untuk radio- } \\ \text { tagging } & \text { kepada } & \text { hewan } & \text { harus }\end{array}$ dipertimbangkan supaya tidak mengganggu perilaku normal hewan (Mech et al., 2002). Banyak perilaku menyimpang yang dapat terjadi dalam 1-2 minggu setelah radiotagging (White and Garrot, 1990).

Pelacakan sinyal radio bisa hilang diakibatkan oleh daya baterai habis, hewan bergerak atau mati di lokasi yang jauh dari daya jangkau pelacakan sinyal radio (Sotoazat, 2006). Ruiz-olmo et al. (1991) melakukan pelacakan pada berang-berang jantan yang masih muda yang sudah dipasang radiotransmitter, selama 25 hari berang-berang bergerak sejauh $20,7 \mathrm{~km}$ dan pergerakan terjauh $9 \mathrm{~km}$ sehari. Ó Néill et al. (2008) memasang implant transmitter pada berang-berang jenis Lutra lutra, dengan jangkauan sinyal bisa dilacak di lapangan $300 \mathrm{~m}$ dan kehilangan kontak tidak sampai sehari setelah dilepaskan karena masuk ke dalam lubang $2 \mathrm{~m}$.

\section{Kesimpulan}

Berdasarkan penelitian yang telah dilakukan, dapat disimpulkan bahwa Kondisi fisik berang-berang cakar kecil pada saat proses penangkapan menggunakan perangkap kaki terdapat cedera pada kaki, dagu, gigi dan jantung membengkak dan perilaku agresif. Kondisi fisik menggunakan perangkap kotak cedera lecet pada hidung dan perilaku tenang dan saat pelepasan bergerak cepat keluar dari kotak. Penangkapan menggunakan perangkap jepit kaki mengakibatkan stress tinggi daripada perangkap kotak multiplek. Pergerakan jelajah satu individu berangberang cakar kecil saat dilepasliarkan dalam waktu 1 x 24 jam sejauh $30 \mathrm{~m}$ dan dalam waktu 2 x 24 jam sejauh $200 \mathrm{~m}$, kemudian hilang kontak. Oleh karena itu penggunaan implant transmitter dalam metoda telemetri untuk berang-berang cakar kecil belum efektif. 


\section{Ucapan Terima Kasih}

Penelitian ini didanai oleh Rufford Small Grants (No. 17544-2) dan IdeaWild. Terimakasih kepada Dr. Ardinis Arbain, Dr. Rizaldi dan Dra. Izmiarti, M.Si yang telah memberikan masukan dan saran selama penelitian. Terimakasih juga kepada Ferdi Andeska dan Hermansah yang telah membantu selama di lapangan.

\section{Daftar Pustaka}

Aadrean. 2011. Ekologi Makan Berangberang Cakar Kecil (Aonyx cinereus) di Area Persawahan Kabupaten Padang Pariaman. Tesis. Universitas Andalas. Padang.

American Veterinary Medical Association. 2008. Literature Review on the Welfare Implications of Legh old Trap Use in Conservation and Research. American Veterinary Medical Association Animal Welfare Division

Arnemo, J.M. 1991. Surgical Implantation of Intraperitoneal Radiotelemetry Devices in European River Otters (Lutra lutra). Proceeding of the $V$. International Otter Colloquium. Habitat 6, Hankensbuttel: 119

Asmoro, P.D. Melisch, \& R. Kusumawardhanio.1994. Hubungan antara Berang-Berang dengan Manusia. Simposium Pertama Mengenai Berang-Berang di Indonesia. Bogor. 7 April 1994.

Belfiore, M. Natalia. 2008. Trapping and Handling of North American River Otters (Lontra Canadensis) in a Managed Marsh. Journal of Zoo and Wildlife Medicine, Vol. 39, No. 1 (maret 2008), pp. 13-20

Blundell, M. Gail, W. John, R. Terry, and K. Lawrence. 1999. Capturing River Otters: A Comparison of Hancock and Leg-Hold Traps. Wildlife Society Bulletin, Vol. 27, No. 1 (Spring, 1999), pp. 184-192

Fernández-Morán, Jesus, Saavedra, Deli., Manteca-Vilanova, Xavier. 2002. Reintroduction of the eurasian otter (Lutra lutra) in northeastern spain: trapping, handling, and medical management. Journal of Zoo and Wildlife Medicine, 33(3):222-227

Foster-Turley, P. A. 1992. Conservation Aspects of the Ecology of Asian Small-Clawed and Smooth Otters on the Malay Peninsula. IUCN Otter Spec. Group Bull. 7: 26-29

Haney, J.C. 2007. Translocations, transmitter effects, and veterinary care of otters (Mustelidae) during reintroduction: An Annotated Bibliography. Conservation Science and Economics Department Defenders of Wildlife

Iossa G, C.D Soulsbury, \& S. Harris. 2007. Mammal trapping: a review of animal welfare standards of killing and restraining traps. Animal Welfare; $16: 335-352$

Larivière, S. 2003. Amblonyx cinereus. Mammalian Species, American Society of Mammalogists, 720, 1-5.

Mech. L.David., Barber, Shannon M. 2002. A critique of wildlife radio-tracking and its use in national parks. A report to the u.s. national park service

Melissen, A. 2000. Eurasian Otter Lutra lutra Husbandry Otter. Otterpark AQUALUTRA.

Ó Néill, L, A. de Jongh, J Ozoliņš, T. de Jong, \& J. Rochford. 2007. Minimising leghold trapping trauma for otters with mobile phone technology. $J$ Wildl Manage 7:2776-2780

Ó Néill, L., P. Wilson, A. de Jongh, T. de Jong, and J. Rochford. (2008). Field techniques for handling, anaesthetising and fitting radiotransmitters to Eurasian otters (Lutra lutra). Eur $J$ Wildl Res. 54:681-687.

Ruiz-Olmo, J., Jimenez, J. \& Marco, I. 1991. Radiotracking a Translocated Otter in Spain. IUCN Otter Spec. Group Bull. 6: 6-7.

Serfass, T. L, R. P. Brooks, T. J. Swimley, L. M. Rymon, \& A. H. Hayden. 1996. Considerations for cap turing, handling and translocating river otters. Wildl. Soc. Bull. 24: 25-31 
Soto-Azat, C, F. Bober, G. Flores, E. Mora, A. Santibanez, \& G. Medina-Vogel. 2006. Reversible Anesthesia In Wild Marine Otters (Lontra Felina) Using Ketamine And Medetomidine. Journal Of Zoo And Wildlife Medicine 37: 535-538.

Soto-Azat, C, F. Boher, G. Flores, R. Monsalve, A. Santibáñe., J. Vianna, \& G. Medinavogel. 2011. Veterinary Management of Marine Otters (Lontra Felina) In Ecological Studies In Chile. IUCN Otter Spec. Group Bull. 28 (A).
Quaglietta, L., V. C. Fonseca, A. Mira, L. Boitani. 2014. Sociospatial organization of a solitary carnivore, the Eurasian otter (Lutra lutra). Journal of Mammalogy. 95(1):140150

Walker, E.P. 1975. Mammals of the World. Third edition. Baltimore, Johns Hopkins Press. 2015 pp.White, G.C., and R.A. Garrott. 1990. Analysis of Wildlife Radio-tracking Data. Academic Press, San Diego, California. 